\title{
US panel backs new approach to risk
}

Washington. A new approach to assessing environmental and public-health risks, allowing the public and scientists to become involved in discussing risks before they are given a formal assessment, has been suggested by the National Research Council (NRC), the operating arm of the US National Academy of Science.

According to officials of leading federal agencies, the report, Understanding Risks: Informing Decisions in a Democratic Society, published in Washington DC last week, could have far-reaching implications for the way in which government uses science to reach decisions about managing such risks.

The suggested approach immediately came under fire from industrial groups, which claim that excessive participation by 'stakeholders' including industry, environmentalists and the general public could swamp objective, scientific riskassessment.

But Harvey Fineberg, dean of the School of Public Health at Harvard University, and chair

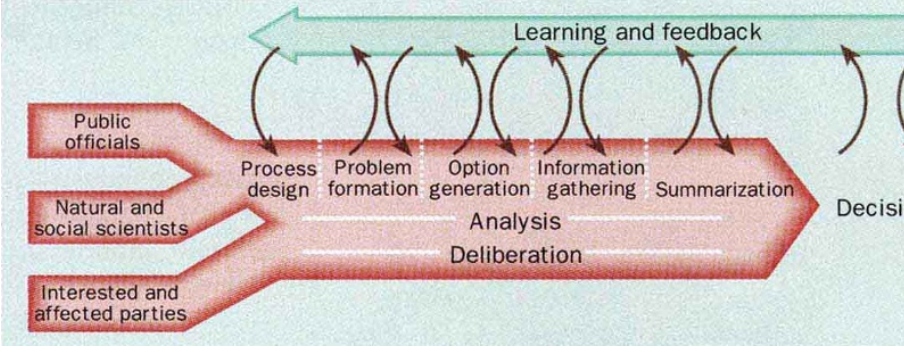
Risky business? The new assessment model involves the public from the start

- and that is disquieting to me," he says. Lewis predicts that science, if mixed up with the policy, "would bring an even more confusing dog's breakfast to the table" than it does already. He warns against "an arranged marriage" between science and policy, from which "there will be no divorce".

Some government officials are also concerned about the degree of integration proposed by the panel. Alwynelle Ahl, director of risk assessment at the Department of Agriculture, says risk assessment is a new function in the department, only starting to establish its independence in the agency.

Risk assessors, she says, are wary of "managers coming in and saying 'this is the result I want and you're going to get it"'. Ahl endorses the general message of the report.

But she warns that "the challenge will be to test the theory of this report in the cauldron of agency decision-making".

Industry fears that endless debate with the public will cloud clear-cut scientific assessment of risks, especially celebrated

military and nuclear sites are cleaned up, for example, the Departments of Defense and of Energy have tried to consult widely before the specific problems of a particular site are assessed, rather than bringing in the public after this has been done to discuss proposed solutions.

But in many other cases, researchers are asked to assess a particular problem - such as the cancer risk from a certain chemical and then step aside while agencies, industry and public interest groups argue about what to do about it.

"Many scientists have felt that they were [just] being asked for a number," says Lynn Goldman, assistant administrator for pesticides and toxic substances at the Environmental Protection Agency, warmly welcoming the report.

Goldman says that the previous approach does not make full use of scientists' skills, and that they could contribute more through "a back and forth process" with agency managers and the public. "You need an iterative process, involving many people," says North.

But the American Industrial Health Council, an industry group which, with several government agencies, helped to fund the study, has denounced its main findings. Steven Lewis, a senior scientist at Exxon, the oil company, and chair of the NRC's science policy committee, says that science has never had a strong enough voice in risk management.

"In order to correct that, the report proposes to partner science and policy up close ones such as the cancer risk posed by pesticides, which it considers to be small.

It supports legislation that would require such assessments both to be published and to be used as the main basis for government regulation. Legislation towards this goal was passed by the House of Representatives last year but is now stalled in the Senate.

According to one congressional staff member involved in drafting that legislation, the NRC report is "full of 'kumbaya' stuff" and "doesn't get to the heart of the problem". North says that the proposed structure "should not make scientists more restricted, it should liberate them, and enable them to participate more fully" in defining and solving environmental and public-health problems.

But the report warns that the proposed consultative processes will be wrecked if one party bales out to attack it in court, or by a direct appeal to the Congress to change laws. "This possibility casts a shadow over the entire process," it observes, since it "can increase alienation and mistrust" among those who were reluctant to get involved in the first place.

Coincidentally, a presidential commission on risk assessment and risk management, established under the 1990 Clean Air Act, issued a draft report last week. It criticized what it termed the "highly fragmented, adversarial system" for risk management in the United States, and called for more and earlier public participation in the process.

Colin Macilwain and not to design new ones.

C. M. 